\title{
Depression In Type 2 Diabetes Mellitus : A Cross-Sectional Study In Tertiary Care Teaching Hospital In India.
}

\author{
P. Varma ${ }^{1}$, R. Kant ${ }^{2}$, P.P Mishra ${ }^{3}$ \\ Department of Internal Medicine, AIIMS, Hrishikesh, India
}

\begin{abstract}
Introduction: In our country, number of patients of diabetes is increasing every year, so of depression. The emotional consequences of diabetes have been scrutinized in a number of studies and varying results about the association of depression with type 2 diabetes mellitus have been found. While depression may contribute to poor diabetes-related outcomes, diabetes and its complications may also contribute to poor depression outcomes. Both conditions may have common underlying biological and behavioural mechanisms, such as genetic susceptibility and common pathophysiological mechanism.

AIM-To assess the prevalence and the factors associated with depression among the patients with type II diabetes mellitus.

Materials and Methods: Single centre, descriptive, cross-sectional study conducted in tertiary care teaching hospital in india for a period of 8 months. 586 type II diabetes patients aged between 30 and 70 years were included. Patients taking mood elevator drugs ,suffering from mental illness, gestational diabetes and type 1 diabetes were excluded from the study. Physicians Health Questionnare-9 (PHQ-9) with a score of $\geq 5$ was used to make the diagnosis of depression.

RESULTS- Prevalence of depression among the diabetic patients found to be $49.48 \%$. Many factors have been found to be associated with increased prevalence of depression among diabetic patients such as age, female gender, house wife, high BMI, diabetes duration, diabetes related complications, comorbid conditions and poor glycaemic control with poor follow-up.

Conclusion: By managing both depression and diabetes concurrently, better outcome in patients and increase in overall quality of life can be achieved. Early detection and treatment of depression by effectively screening all diabetic patients for depression would help to bring down the severity of depression among these patients.
\end{abstract}

Key Words: Type 2 diabetes mellitus,depression, quality of life .

\section{INTRODUCTION}

According to the International Diabetes Federation "diabetes is one of the largest global health emergencies of the 21 st century"1. The World Health Organization (WHO) predicts that more than 360 million people worldwide will have diabetes by $2030^{2}$. Diabetes is increasing in every country, but eighty percent of people with diabetes live in low income and around half of those are undiagnosed ${ }^{3}$. Depression is a common and very serious medical disease with a lifetime prevalence ranging from approximately $11 \%$ in low-income countries to
$15 \%$ in high-income countries ${ }^{4}$. On the other hand, depression may increase the risk of developing type 2 diabetes with $60 \%{ }^{5,6}$.

There has been increased attention given to how psychological issues affecting Diabetes Mellitus (DM) self-management, as well as the psychological consequences of having the diabetes. Being diagnosed with diabetes is a major life stress. It requires a large number of physical and mental accommodations. The individual must learn about a complex system of dietary and medical 
interventions with lifestyle modification. This can consume a lot of energy of individual. As a result of this they go through the typical stages of mourning which include denial, anger, depression and acceptance ${ }^{7}$.

It seems that there is a bidirectional association between diabetes and depression, a complex relation that might share biological mechanisms, whose understanding could provide a better treatment and improve the outcomes for these pathologies ${ }^{7,8}$. The aim of this study is to determine the prevalence of depression and the factors associated with it among patient with diabetes mellitus.

The objectives are to determine the prevalence of depression among patient with diabetes mellitus and to identify factors associated with depression among patients with type 2 diabetes mellitus.

\section{METHODS}

This was an Institution based cross-sectional study design was used to assess associated factors of depression among type 2 diabetic outpatients. The study was conducted from July, 2016 to march 2017. Patients -All type 2 diabetes out-patients on follow up treatment in diabetes clinic.

Subjects and Selection-T2 DM patients aged between 30 and 70 years were included in our study. We chose a structured questionnaire PHQ-9. The Inclusion Criteria were Individuals diagnosed as Type-2 Diabetes Mellitus and Age between 30 to 70 years. The exclusion criteria were Individuals with type 1 diabetes mellitus, Patients taking mood elevator drugs, suffering from mental illness,gestational diabetes and type 1 diabetes, All data was entered and analyzed using Statistical Programfor Social Sciences (SPSS) version 12. 0 (SPSS Inc.2003).

\section{RESULTS}

In our study the prevalence of depression among the diabetic patients was $49.48 \%$.

Among the various clinical parameters we found a significant association $(\mathrm{p}<.01)$ for patients with gender, occupation, income, BMI, duration of diabetes, complication of diabetes, uncontrolled blood sugar of more than $200 \mathrm{mgs} / \mathrm{dl}$.

Table -1 below enumerates all the above factors and the level of depression among the patient. Further Figures1.1 to 1.10 are graphical depiction of above data

\section{TABLE-1 SHOWING FACTORS AND THE LEVEL OF DEPRESSION AMONG THE PATIENT}

\begin{tabular}{|c|c|c|c|c|}
\hline Demographic factors & $\begin{array}{l}\text { DEPRESSIO } \\
\text { N PRESENT }\end{array}$ & $\begin{array}{l}\text { DEPRESSION- } \\
\text { ABSENT }\end{array}$ & $\begin{array}{l}\text { CHI-SQUARE } \\
\text { VALUE }\end{array}$ & P- VALUE \\
\hline & 290 & 296 & & \\
\hline $\begin{array}{l}\text { Gender } \\
\text { Male }(\mathrm{n}=310) \\
\text { Female }(\mathrm{n}=276)\end{array}$ & $\begin{array}{l}133(42.90 \%) \\
157(56.88 \%)\end{array}$ & $\begin{array}{l}177(57.09 \%) \\
119(43.11 \%)\end{array}$ & 11.4168 & 0.000728 \\
\hline $\begin{array}{l}\text { Age } \\
\begin{array}{r}30-40 \mathrm{yrs}(\mathrm{n}=226) \\
41-70 \mathrm{yrs}(\mathrm{n}=360)\end{array}\end{array}$ & $\begin{array}{l}106(46.90 \%) \\
184(51.11 \%)\end{array}$ & $\begin{array}{l}120(53.09 \%) \\
176(48.88 \%)\end{array}$ & 0.9837 & 0.32128 \\
\hline $\begin{array}{l}\text { Religion } \\
\text { Hindu }(n=270) \\
\text { Muslim }(n=216) \\
\text { Christian }(n=24) \\
\text { Sikhs/sindhi }(n=76)\end{array}$ & $\begin{array}{l}133(49.25 \%) \\
102(47.22 \%) \\
5(20.83 \%) \\
50(65.78 \%)\end{array}$ & $\begin{array}{l}137(50.74 \%) \\
114(52.77 \%) \\
19(79.16 \%) \\
26(34.21 \%)\end{array}$ & 16.4118 & 0.000934 \\
\hline $\begin{array}{l}\text { Education } \\
\text { Illitrate }(\mathrm{n}=230) \\
\text { Educated(n=356) }\end{array}$ & $\begin{array}{l}104(45.21 \%) \\
186(52.24 \%)\end{array}$ & $\begin{array}{l}126(54.78 \%) \\
170(47.75 \%)\end{array}$ & 2.7623 & 0.96509 \\
\hline
\end{tabular}




\begin{tabular}{|c|c|c|c|c|}
\hline $\begin{array}{l}\text { Occupation } \\
\text { Service }(n=170) \\
\text { Private job }(n=110) \\
\text { Farmer }(n=154) \\
\text { Bussiness }(n=152)\end{array}$ & $\begin{array}{l}102(60 \%) \\
60(54.54 \%) \\
46(29.87 \%) \\
82(53.94 \%)\end{array}$ & $\begin{array}{l}68(40 \%) \\
50(45.45 \%) \\
108(70.12 \%) \\
70(46.05 \%)\end{array}$ & 33.5596 & 0.00001 \\
\hline $\begin{array}{l}\text { Income } \\
<10000 \mathrm{rs}(\mathrm{n}=350) \\
>10000 \mathrm{rs}(\mathrm{n}=236)\end{array}$ & $\begin{array}{l}203(58.0 \%) \\
87(36.86 \%)\end{array}$ & $\begin{array}{l}147(42.0 \%) \\
149(63.13 \%)\end{array}$ & 25.1893 & 0.00001 \\
\hline $\begin{array}{l}\text { Body mass index } \\
<25(\mathrm{n}=240) \\
>25(\mathrm{n}=346)\end{array}$ & $\begin{array}{l}91(37.91 \%) \\
199(57.51 \%)\end{array}$ & $\begin{array}{l}149(62.08 \%) \\
147(42.48 \%)\end{array}$ & 21.7725 & 0.00001 \\
\hline $\begin{array}{l}\text { Diabetes duration } \\
<5 \text { years }(\mathrm{n}=223) \\
5 \text { to } 10 \mathrm{yrs}(\mathrm{n}=199) \\
>10 \mathrm{yrs}(\mathrm{n}=164)\end{array}$ & $\begin{array}{l}136(60.98 \%) \\
68(34.17 \%) \\
86(52.43 \%)\end{array}$ & $\begin{array}{l}87(39.01 \%) \\
131(65.82 \%) \\
78(47.56 \%)\end{array}$ & 31.0436 & 0.00001 \\
\hline $\begin{array}{c}\text { Co-morbid illness } \\
\operatorname{present}(\mathrm{n}=310) \\
\text { absent }(\mathrm{n}=276)\end{array}$ & $\begin{array}{l}167(53.83 \%) \\
123(44.56 \%)\end{array}$ & $\begin{array}{l}143(46.12 \%) \\
153(55.43 \%)\end{array}$ & 5.058 & 0.024512 \\
\hline $\begin{array}{l}\text { Diabetic complications } \\
\text { present }(n=138) \\
\text { absent }(n=448)\end{array}$ & $\begin{array}{l}97(70.28 \%) \\
193(43.08 \%)\end{array}$ & $\begin{array}{l}41(29.71 \%) \\
255(56.91 \%)\end{array}$ & 31.2468 & 0.00001 \\
\hline $\begin{array}{l}\text { Controlled diabetes } \\
\text { yes }(\mathrm{n}=370) \\
\text { no }(\mathrm{n}=216)\end{array}$ & $\begin{array}{l}140(37.83 \%) \\
150(69.44 \%)\end{array}$ & $\begin{array}{l}230(62.16 \%) \\
66(30.55 \%)\end{array}$ & 54.5028 & 0.00001 \\
\hline
\end{tabular}

In our study the prevalence of depression among the diabetic patients was $49.5 \%$ and based on scores we graded them no depression (50.51\%), mild to moderate depression( $42.32 \%)$ and severe depression $(7.16 \%)$.

TABLE 2- DISTRIBUTION OF THE PATIENTS BASED ON THEIR LEVELS OF DEPRESSION

\begin{tabular}{|l|l|l|}
\hline Level of depression & FREQUENCY N=586 & PERCENTAGE \% \\
\hline No depression $(0-10)$ & 296 & $50.51 \%$ \\
\hline Mild to moderate depression $(5-19)$ & 248 & $42.32 \%$ \\
\hline Severe depression $(20-27)$ & 42 & $7.16 \%$ \\
\hline Total & 586 & $100 \%$ \\
\hline
\end{tabular}

\section{DISCUSSION}

Depression being one of the major psychiatric disorders would have a negative effects towards the quality of life, treatment outcome and medication adherence of patients with diabetes In our study the prevalence of depression in diabetic patient was $49.48 \%$. The result of our study is higher than study done by Ali et al $(27.05 \%)^{9}$, Jameel Nasser et al (33.3\%)10, Al Ghamdi AA (34\%) $)^{11}$, Waleed M Sweileh et al $(40 \%)^{12}$,Subhash Das et al $(41 \%)^{13}$. In a study done by in a Ranjan Das et al in urban areas of Kolkata, $46.15 \%$ met criteria for depression ${ }^{14}$.

The depression prevalence in different studies could be due to difference in sociodemographic characteristics, ethnicity, geographical area and 
life style of individuals. In our study depression was associated was females, lower income, BMI, presence of complications, duration of diabetes, uncontrolled blood sugar and similar findings were observed by Amit Raval et $\mathrm{al}^{14}$, Waleed $\mathrm{M}$ Sweileh et $\mathrm{al}^{12}$ and Jameel Nasser et $\mathrm{al}^{10}$. We found a significant correlation between earning. Individuals with low earning face the twin burdens of paying for health care, which in india is largely out-ofpocket, and meeting the needs of their children. In our study statistically significant association was found between fasting blood sugar levels and depression. Increasing FBS levels were observed in depressed individuals when comparedwithnondepressed individuals. Similar findings were observed in a study done by Bajaj et $\mathrm{a}{ }^{16}$. About $43.5 \%$ of the study participants experienced somewhat difficulty in carrying out daily activities as per the PHQ-9 questionnaire. This could have led to poor compliance to medication which could have led to poor outcome of the disease. Similar findings were observed in study done by Habtewold et al in Ethiopia9. Diabetic complications were found to be strongly associated with increasing depression severity. Similar findings were observed in a study done by Joseph et al in Mangalore ${ }^{30}$. $\mathrm{DM}$ is a chronic physical disorder that requires lifestyle alterations and medication adherence for its successful treatment and better quality of life.

\section{CONCLUSION}

The prevalence of depression among the study patient was found to be $49.48 \%$. Depression was found to be higher in female gender, higher age, and lower socioeconomic status. Presence of complications, duration of treatment was found to be significantly associated with depression. Although majority of depressed patients were unrecognized and untreated.Better outcome in patients overall care and quality of life will be achieved by managing both the depression and diabetes concurrently. Regular assessment of Diabetics for depression is required for wellbeing of diabetic patients. Integrated approach by physician and psychiatrists for effective management of diabetes and counselling of patients will help in preventing the depression.

\section{REFERENCES}

1. International Diabetes Federation. IDF Diabetes, 7 ed., 2015, Brussels, Belgium:IDF, http://www. diabetesatlas.org.

2. World Health Organization. Diabetes Action Now. DiabeteVoice.2004;49(2)27-31

3. International Diabetes Federation. Diabetes Atlas. 4. Brussels, Belgium: IDF; 2011.

4. Bromet E, Andrade LH, Hwang I, Sampson NA, Alonso J, de GG, de GR, Demyttenaere K, Hu C, Iwata N, Karam AN, Kaur J, Kostyuchenko S, Lepine JP, Levinson D, Matschinger H, Mora ME, Browne MO, Posada-Villa J, Viana MC, Williams DR, Kessler RC. Cross-national epidemiology of DSM-IV major depressive episode. BMC Med. 2011;

5. Mezuk B, Eaton WW, Albrecht S, Golden SH. Depression and type 2 diabetes over the lifespan: a meta-analysis. Diabetes Care. 2008; 31:2383-2390.

6. Rubin RR, Ma Y, Marrero DG, Peyrot M, BarrettConnor EL, Kahn SE, Haffner SM, Price DW, Knowler WC. Elevated depression symptoms, antidepressant medicine use, and risk of developing diabetes during the diabetes prevention program. Diabetes Care. 2008; 31:420-426.

7. Sridhar GR,Madhu K. Psychosocial and cultural issues in diabetes mellitus. Curr Sci.2002;83:155664

8. Berge LI, Riise T. Comorbidity between Type 2 Diabetes and Depression in the Adult Population: Directions of the Association and Its Possible Pathophysiological Mechanisms. Int J Endocrinol. 2015; 2015:164760.

9. Ali N, Jyotsna VP, Nand Kumar, et al. Prevalence of Depres-sion Among Type 2 Diabetes Compared to Healthy Non Di-abetic Controls. Journal of the association of physicians of In-dia 2013; 61: 31-3.

10. Leonard EE, Ellis C (2008) The Effects of Depression on Diabetes Knowledge, Diabetes SelfManagement, and Perceived Control in Indigent Patients with Type 2 Diabetes. Diabetes technology \& therapeutics 10: 213-219.

11. Nasser J, Habib F, Hasan M, et al. Prevalence of Depression among People with Diabetes Attending Diabetes Clinics at Primary Health Settings. Bahrain Medical Bulletin 2009; 31 (3):1-12.

12. Al-Ghamdi AA. A high prevalence of depression among di-abetic patients at a teaching hospital in Western Saudi Ara-bia. Neurosciences (Riyadh). 2004;9(2):108-12.

13. Sweileh WM, Abu HM, Aljabi SW, et al. Prevalence 
of de-pression among people with type 2 diabetes mellitus: a cross sectional study in Palestine. BMC Public Health.2014; 14:163.

14. Raval A, Dhanaraj E, Bhansali A, et al. Prevalence \&determi-nants of depression in type 2 diabetes patients in a tertiary care centre. Indian Journal of Medical Research. 2010;132.195-200.

15. Moulton CD, Pickup JC, Ismail K. The link between depression and diabetes: the search for shared mechanisms. Lancet Diabetes Endocrinol. 2015; 3:461-471.

16. Bajaj S, Agarwal SK, Varma A, Singh VK. Singh. Association of depression and its relation with complications in newly diagnosed type 2 diabetes. Indian J EndocrinolMetab. 2012;16(5):759-63. 